\title{
Nutrient management in jackfruit (Artocarpus heterophyllus Lam.) under rainfed condition
}

\author{
M. Laishram and *S. N. Ghosh \\ Department of Fruits and Orchard Management, Faculty of Horticulture \\ Bidhan Chandra Krishi Viswavidyalaya, Mohanpur - 741 252, West Bengal, India \\ *E-mail: profsnghosh@yahoo.co.in
}

\begin{abstract}
An investigation was taken up on eight years old seedling trees of jackfruit, planted at $10 \times 10$ m spacing at the Horticultural Research Station, Mondouri (Nadia, West Bengal) of the Bidhan Chandra Krishi Viswavidyalaya with a view to know the effect of different organic manures and inorganic nutrients (N, P and K) on production, fruit quality, soil heath and foliar NPK status. Results from the three consecutive years of investigation, it was revealed that highest dose of NPK ( $N_{500} P_{300} K_{300}$ g/tree/year) resulted in highest yield (76.3 kg / tree) but gave lower BCR (benefit cost ratio) of 1.13 while its lowest dose $\left(N_{200} P_{100} K_{100}\right.$ g/tree/year) gave higher BCR of 2.00. Among the organic manures, vermicompost at $4.00 \mathrm{~kg} /$ tree/year produced second higher yield $(56.3 \mathrm{~kg} /$ tree) with best quality fruits and this treatment resulted in highest BCR of 2.17. Soil NPK status and $\mathrm{pH}$ improved under different treatments as compared to respective initial values. Foliar NPK values were differed among the treatments although it could not be correlated to the fruit yield.
\end{abstract}

Key words: Economics, fruit yield and quality, inorganic nutrients, organic manures

\section{INTRODUCTION}

Jackfruit (Artocarpus heterophyllus Lam) is one of the most important minor fruit crops in tropical and sub-tropical regions. Every part of the tree and fruit is used for various purposes. The green ripe fruit is consumed as vegetable while ripe one is used as fresh fruit due to its nutritional value and delicious taste. Systematic jackfruit plantation in the country is very rare. Most of the cases it is found in homestead garden and in roadside plantation. Jackfruit is reported to be a suitable choice degraded lands in Asia and Africa. Generally, jackfruit trees are not given fertilizers and thus little, is known about its fertilizer requirement. However, the trees need good nutrition to promote regular and good bearing. It is well established that quantity and type of fertilizer requirement of a fruit crop depends on the age and agro-climatic condition particularly fertility of the soil in a region. Tandon (1987) recommended $600 \mathrm{~g} \mathrm{~N}, 300 \mathrm{~g} \mathrm{P}, 240 \mathrm{~g} \mathrm{~K}$ and $50 \mathrm{~kg}$ of FYM for a bearing jackfruit tree grown at a spacing of $10 \mathrm{~m} \times 10 \mathrm{~m}$ inn the state of Karnataka (India) while Hossain. and Haq (2006) suggested a manorial dose of $20 \mathrm{~g}$ urea, $300 \mathrm{~g}$ triple super phosphate, $500 \mathrm{~g}$ Muriate of potash, $250 \mathrm{~g}$ gypsum and $25 \mathrm{~kg}$ FYM for an 8-10 years old jack tree. Although, there are some reports about application of N, P and K singly or in combination with FYM in jackfruit but there is no report or literature available regarding effect of single application of different organic manures and inorganic nutrients (viz. N, P and K) on fruiting and quality aspects of jackfruit. Due to deleterious effect of chemical fertilizers on soil, plant and environment, there is now an urgent need to know the effect of various organic manures vs chemical fertilizers (NPK) on jackfruit and also their impact on soil fertility and economic profitability.

The experiment was conducted on eight years old seedling jackfruit trees planted at $10 \times 10 \mathrm{~m}$ spacing having uniform growth at the Horticultural Research Station of Bidhan Chandra Krishi Viswavidyalaya, Mondouri, Nadia, West Bengal during 2010-2013. The site is situated at $23.5^{\circ}$ North latitude and $80^{\circ} 34^{\prime}$ East longitude having an altitude of $9.75 \mathrm{~m}$ above mean sea level. The experimental site has gangetic new alluvial 
soil with sandy clay loam in texture. Before undertaking the experiment, composite soil samples of the field was taken from the depth of 0-30 cm for analysis. Available $\mathrm{N}, \mathrm{P}$ and $\mathrm{K}$ of the soil were $178.2,19.7$ and $302.2 \mathrm{~kg} /$ ha and $\mathrm{pH}$ was 6.60. Available $\mathrm{Ca}, \mathrm{Mg}$ and $\mathrm{Zn}$ content in the soil were $36.4 \mu \mathrm{g} / \mathrm{g}, 40.2 \mu \mathrm{g} / \mathrm{g}$ and $16.7 \mu \mathrm{g} / \mathrm{g}$, respectively. The climatic condition of the Research station was humid sub-tropical.

There were nine treatments viz., cow dung at $20 \mathrm{~kg}$ and $40 \mathrm{~kg}$; mustard cake at $2 \mathrm{~kg}$ and $4 \mathrm{~kg}$; vermicompost $4 \mathrm{~kg}$ and $8 \mathrm{~kg} /$ tree/year; $\mathrm{N}_{200} \mathrm{P}_{100} \mathrm{~K}_{100}$ g, $\mathrm{N}_{400} \mathrm{P}_{200} \mathrm{~K}_{200}, \mathrm{~N}_{500} \mathrm{P}_{300} \mathrm{~K}_{300} \mathrm{~g} /$ tree/year. The source of $\mathrm{N}, \mathrm{P}$ and $\mathrm{K}$ were urea, single super phosphate and muriatic of potash, respectively. The treatments were applied following randomized block design having three replications of each. The treatments were applied in a two feet wide circular trench at three feet away from the trunk in two splits i.e., in June (during on set of monsoon) and in September. No irrigation was provided during the period of investigation. Plant protection measures were taken against pests and diseases as and when it was necessary. Before imposition of treatments in earlier years, the plants were maintained under rainfed condition with minimum fertilization i.e., $20 \mathrm{~kg}$ cow dung $+\mathrm{N}_{200} \mathrm{P}_{100} \mathrm{~K}_{100} \mathrm{~g} /$ plant/year.
Observation on fruit yield, physico-chemical characteristics of fruits were taken. Fruit setting was determined by dividing the total number of fruits set with total number of female spike. It wass expressed in percent by multiplying with 100 . Fruit retention was determined by dividing the number of fruits at harvest and initial number of set fruits. It is expressed in per cent by multiplying with 100 . TSS of fruit was estimated by hand refractrometer while acidity, reducing sugars, total sugars and vitamin $\mathrm{C}$ content of the fruit flakes were determined following standard method (A. O. A.C. 1990). The soil $\mathrm{pH}$ was determined by using glass electrode $\mathrm{pH}$ meter; soil available nitrogen content was estimated following the method as described by Jackson (1973); available phosphorus by Bray and Kurtz (1945) and available potassium by Flame photometry (Black, 1965). Foliar nitrogen content was estimated by microkjeldal method (Black, 1965); phosphorus by vandomolybdate phosphoric acid (Jackson, 1967) and potassium by photometer (Piper, 1956).

\section{Fruit setting and Fruit retention}

By adopting different nutrient management practices, a significant difference in fruit setting and its retention was observed in jackfruit (Table 1). In

\section{Table 1. Effect of organic manures and inorganic nutrients (NPK) on fruit setting, fruit retention and yield of jackfruit}

\begin{tabular}{|c|c|c|c|c|c|c|}
\hline \multirow{2}{*}{$\begin{array}{l}\text { Treatment } \\
\text { per } \\
\text { tree / year }\end{array}$} & \multirow{2}{*}{$\begin{array}{c}* \text { Fruit } \\
\text { setting } \\
(\%)\end{array}$} & \multirow{2}{*}{$\begin{array}{l}{ }^{*} \text { Fruit } \\
\text { retention } \\
(\%)\end{array}$} & \multicolumn{4}{|c|}{ Fruit yield/kg/tree } \\
\hline & & & $1^{\text {st }}$ year & $2^{\text {nd }}$ year & $3^{\text {rd }}$ year & Pooled \\
\hline Cowdung $-20 \mathrm{~kg}$ & $66.3(54.51)$ & $50.2(45.11)$ & 22.8 & 70.1 & 66.5 & 53.1 \\
\hline Cowdung $-40 \mathrm{~kg}$ & $55.6(48.22)$ & $51.1(45.63)$ & 38.0 & 40.1 & 38.0 & 38.7 \\
\hline Mustard Cake $-2 \mathrm{~kg}$ & $57.3(49.20)$ & $45.3(42.30)$ & 20.7 & 60.3 & 44.2 & 41.7 \\
\hline Mustard Cake $-4 \mathrm{~kg}$ & $68.3(55.73)$ & $58.4(49.84)$ & 40.4 & 60.1 & 58.2 & 52.9 \\
\hline Vermicompost $-4 \mathrm{~kg}$ & $66.8(54.82)$ & $59.4(50.42)$ & 27.7 & 75.8 & 65.3 & 56.3 \\
\hline Vermicompost $-8 \mathrm{~kg}$ & $65.2(53.85)$ & $44.9(42.07)$ & 34.8 & 54.3 & 45.3 & 44.8 \\
\hline $\mathrm{N}_{200} \mathrm{P}_{100} \mathrm{~K}_{100} \mathrm{~g}$ & $70.0(56.79)$ & 53.1(46.78) & 43.3 & 54.1 & 58.4 & 51.9 \\
\hline $\mathrm{N}_{400} \mathrm{P}_{200} \mathrm{~K}_{200} \mathrm{~g}$ & 73.4(58.95) & $59.7(50.59)$ & 44.0 & 56.7 & 77.4 & 59.4 \\
\hline $\mathrm{N}_{500} \mathrm{P}_{300} \mathrm{~K}_{300} \mathrm{~g}$ & $76.1(60.73)$ & 65.1(53.79) & 37.7 & 86.4 & 104.7 & 76.3 \\
\hline S.Em \pm & 1.01 & 1.06 & 6.40 & 9.63 & 11.54 & 6.42 \\
\hline C.D. at $5 \%$ & 2.14 & 2.25 & 13.56 & 20.41 & 24.47 & 13.62 \\
\hline
\end{tabular}

* Average of last 2 years

Figures in the brackets are angular transformed value 
general fruit setting and retention were higher in trees with chemical fertilizers as compared to organic manures and highest fruit setting $(76.1 \%)$ and retention $(65.1 \%)$ were noted in tree receiving highest dose of NPK $\left(\mathrm{N}_{500} \mathrm{P}_{300} \mathrm{~K}_{300-} \mathrm{g} /\right.$ year $)$. Higher fruit setting and its retention in trees with higher dose of inorganic fertilizers may be due to availability of sufficient amount of nutrients mainly $\mathrm{N}$, which is essential for protein bio-synthesis (Klein and Weinbaum, 1984) and the fact that the developing fruitlets required sufficient amount of proteins (Bouranis et al., 1999). Among the organic manures, mustard cake at $4 \mathrm{~kg}$ and verimicompost at $4 \mathrm{~kg} /$ tree were better in respect of fruit setting and retention.

\section{Fruit yield}

It is clear from the data presented in Table 1 that different doses of organic manures and inorganic sources of nutrients have significant effect on yield of jackfruit. In case of inorganic fertilizers, yield was increased with increase dose of nutrients and highest yield of $76.3 \mathrm{~kg}$ was recorded from the tree receiving highest dose of nutrients $\left(\mathrm{N}_{500} \mathrm{P}_{300} \mathrm{~K}_{300} \mathrm{~g} /\right.$ tree $)$ and this treatment was found to be the best in yield improvement as compared to other treatments of organic manures and inorganic fertilizers. Highest yield from the trees receiving highest dose of NPK might be due to continuous supply of N, P and K which fortifies the tree health and support fruit retention capacity at early stages, thus ultimately gave higher final fruit retention and improved yield per tree (Anwar et al., 2011). Among the organic manures, vermicompost at $4 \mathrm{~kg} /$ tree resulted in maximum jack yield $(56.3 \mathrm{~kg} /$ tree $)$ followed by cowdung at $20 \mathrm{~kg} /$ tree $(53.1 \mathrm{~kg} /$ tree $)$ and mustard cake at $4 \mathrm{~kg} /$ tree $(52.9$ $\mathrm{kg} /$ tree) and these yield variation was statistically at par among themselves.

\section{Fruit weight}

Fruit weight of jack was significantly varied due to application of organic manures and in organic nutrients at different doses (Table 2). Maximum fruit weight $(6.2 \mathrm{~kg})$ was recorded from the tree that, received highest dose of NPK $\left(\mathrm{N}_{500} \mathrm{P}_{300} \mathrm{~K}_{300} \mathrm{~g} /\right.$ tree $)$ closely followed by varmicompost at $4.00 \mathrm{~kg} /$ tree $(6.1$ $\mathrm{kg})$. Lowest levels of NPK $\left(\mathrm{N}_{200} \mathrm{P}_{100} \mathrm{~K}_{100} \mathrm{~g} /\right.$ tree $)$ gave minimum weight of fruit $(4.4 \mathrm{~kg})$ which clearly indicated that jack requires a sizeable amount of nutrients like NPK for their bulky fruit growth.

\section{Edible flake and seed content}

In ripe jack, flake is the edible part which is sweet, aromatic and delicious in taste. The edible flake content was maximum $(42 \%)$ in the fruit of the tree which received highest dose of NPK $\left(\mathrm{N}_{500} \mathrm{P}_{300} \mathrm{~K}_{300} \mathrm{~g} /\right.$ tree) followed by the tree with mustard cake at $4.0 \mathrm{~kg}$ $(41.9 \%)$ and vermicompost at $4.0 \mathrm{~kg}(40.8 \%)$. Minimum edible flake content (37.7\%) was recorded from the fruit of the tree that, received lowest dose of NPK $\left(\mathrm{N}_{100} \mathrm{P}_{100} \mathrm{~K}_{100} \mathrm{~g} /\right.$ tree) (Table 2).

Seed of the jack is also edible. In green jack, which is very popular as vegetable jack, seed is soft and consumed alongwith the hard flake while in ripe jack, it is discarded and consumed as vegetable or used for preparation of many by-products. The seed content in jack was varied due to application of different types of manures and fertilizers (Table 2). Highest seed content $(14.7 \%)$ was recorded from the tree that received highest dose of NPK $\left(\mathrm{N}_{500} \mathrm{P}_{300} \mathrm{~K}_{300}\right.$ g/tree) and lowest seed content (11.5\%) was from the tree with lowest NPK $\left(\mathrm{N}_{200} \mathrm{P}_{100} \mathrm{~K}_{100} \mathrm{~g} /\right.$ tree $)$.

\section{Fruit quality}

The chemical parameters of fruit showed a significant variation in response to application of different nutrient sources (Table 2). The highest TSS, $\left(25.2^{\circ}\right.$ brix $)$, reducing sugar $(6.92 \%)$ total sugar (17.90\%) and vitamin C (11.2 mg/ $100 \mathrm{~g})$ content were recorded from the fruit of the tree that received vermicompost at $4.0 \mathrm{~kg} /$ tree highest followed by highest dose of NPK $\left(\mathrm{N}_{500} \mathrm{P}_{300} \mathrm{~K}_{300}\right.$ g/year). Highest value of different fruit quality parameters recorded from the tree with vearmicompost at $4 \mathrm{~kg} /$ tree and highest dose of NPK may be explained from the fact that the tree synthesized more amount of carbohydrate and sugars due to greater availability of required $\mathrm{N}$ and $\mathrm{K}$ which ultimately driven from the 'source' to fruit which act as 'sink' of the nutrients as reported by various workers in different fruit crops (Usherwood, 1985; Bhargava et al., 1993).

\section{Leaf NPK content}

Foliar NPK content was significantly varied due to application of different doses of organic manures and inorganic nutrients (Table 3). Maximum foliar 
Table 2. Effect of organic manures and inorganic nutrients (NPK) on physio-chemical characteristics of jackfruit (Average of last 2 years)

\begin{tabular}{|l|c|c|c|c|c|c|c|c|}
\hline $\begin{array}{l}\text { Treatment } \\
\text { per } \\
\text { tree / year }\end{array}$ & $\begin{array}{c}\text { Fruit } \\
\text { weight } \\
(\mathrm{kg})\end{array}$ & $\begin{array}{c}\text { Edible } \\
\text { Flake } \\
(\%)\end{array}$ & $\begin{array}{c}\text { Seed } \\
(\%)\end{array}$ & $\begin{array}{c}\text { TSS } \\
\left({ }^{\circ} \mathrm{B}\right)\end{array}$ & $\begin{array}{c}\text { Acidity } \\
(\%)\end{array}$ & $\begin{array}{c}\text { Reducing } \\
\text { sugar } \\
(\%)\end{array}$ & $\begin{array}{c}\text { Total } \\
\text { sugar } \\
(\%)\end{array}$ & $\begin{array}{c}\text { Vitamin } \\
\mathrm{C} \\
(\mathrm{mg} / 100 \mathrm{~g})\end{array}$ \\
\hline Cowdung $-20 \mathrm{~kg}$ & 5.5 & 39.2 & 12.9 & 22.7 & 0.22 & 6.50 & 16.00 & 10.3 \\
\hline Cowdung-40 kg & 5.6 & 39.1 & 13.3 & 21.7 & 0.25 & 6.28 & 15.00 & 10.0 \\
\hline Mustard Cake-2 kg & 5.9 & 39.6 & 12.7 & 22.7 & 0.22 & 5.69 & 15.56 & 9.4 \\
\hline Mustard Cake-4 kg & 6.0 & 41.3 & 13.6 & 23.0 & 0.25 & 6.81 & 16.40 & 9.8 \\
\hline Vermicompost $-4 \mathrm{~kg}$ & 6.1 & 40.8 & 12.8 & 25.2 & 0.28 & 6.92 & 17.90 & 11.2 \\
\hline Vermicompost-8 kg & 5.9 & 39.0 & 12.6 & 22.9 & 0.27 & 5.74 & 16.20 & 9.0 \\
\hline $\mathrm{N}_{200} \mathrm{P}_{100} \mathrm{~K}_{100} \mathrm{~g}$ & 4.4 & 37.7 & 11.5 & 23.6 & 0.23 & 6.31 & 14.97 & 9.8 \\
\hline $\mathrm{N}_{400} \mathrm{P}_{200} \mathrm{~K}_{200} \mathrm{~g}$ & 5.0 & 38.7 & 13.6 & 23.8 & 0.32 & 6.50 & 16.81 & 10.1 \\
\hline $\mathrm{N}_{500} \mathrm{P}_{300} \mathrm{~K}_{300} \mathrm{~g}$ & 6.2 & 42.0 & 14.7 & 25.0 & 0.35 & 6.91 & 17.85 & 11.0 \\
\hline S.Em \pm & 0.09 & 0.38 & 0.35 & 0.26 & 0.01 & 0.17 & 0.27 & 0.21 \\
\hline C.D. at 5\% & 0.19 & 0.81 & 0.75 & 0.56 & 0.02 & 0.37 & 0.58 & 0.45 \\
\hline
\end{tabular}

Table 3. Effect of organic manures and inorganic nutrients on foliar and soil NPK content and soil pH in jackfruit orchard (Average of last 3 years)

\begin{tabular}{|c|c|c|c|c|c|c|c|}
\hline \multirow{2}{*}{$\begin{array}{l}\text { Treatment } \\
\text { per } \\
\text { tree / year }\end{array}$} & \multicolumn{3}{|c|}{ Foliar content (dry weight basis) } & \multicolumn{3}{|c|}{ In soil $(0-30 \mathrm{~cm}$ depth $)$} & \multirow[b]{2}{*}{$\mathrm{pH}$} \\
\hline & $\begin{array}{c}\text { Nitrogen } \\
(\%)\end{array}$ & $\begin{array}{c}\text { Phosphorus } \\
\%\end{array}$ & $\begin{array}{c}\text { Potassium } \\
(\%)\end{array}$ & $\begin{array}{c}\text { Nitrogen } \\
\text { (kg/ha) }\end{array}$ & $\begin{array}{c}\mathrm{P}_{2} \mathrm{O}_{5} \\
(\mathrm{~kg} / \mathrm{ha})\end{array}$ & $\begin{array}{c}\mathrm{K}_{2} \mathrm{O} \\
(\mathrm{kg} / \mathrm{ha})\end{array}$ & \\
\hline Cowdung $-20 \mathrm{~kg}$ & 1.55 & 0.34 & 0.76 & 182.2 & 20.75 & 329.92 & 6.71 \\
\hline Cowdung $-40 \mathrm{~kg}$ & 1.36 & 0.32 & 0.72 & 183.8 & 21.71 & 332.79 & 6.66 \\
\hline Mustard Cake $-2 \mathrm{~kg}$ & 1.54 & 0.35 & 0.67 & 182.8 & 22.53 & 328.84 & 6.72 \\
\hline Mustard Cake $-4 \mathrm{~kg}$ & 1.56 & 0.36 & 0.68 & 184.8 & 22.81 & 331.88 & 6.69 \\
\hline Vermicompost $-4 \mathrm{~kg}$ & 1.57 & 0.39 & 0.67 & 182.9 & 21.82 & 327.67 & 6.70 \\
\hline Vermicompost $-8 \mathrm{~kg}$ & 1.50 & 0.36 & 0.63 & 184.4 & 22.64 & 330.54 & 6.79 \\
\hline $\mathrm{N}_{200} \mathrm{P}_{100} \mathrm{~K}_{100} \mathrm{~g}$ & 1.48 & 0.35 & 0.67 & 183.8 & 22.45 & 328.28 & 6.75 \\
\hline $\mathrm{N}_{400} \mathrm{P}_{200} \mathrm{~K}_{200} \mathrm{~g}$ & 1.56 & 0.37 & 0.72 & 185.2 & 22.40 & 332.78 & 6.73 \\
\hline $\mathrm{N}_{500} \mathrm{P}_{300} \mathrm{~K}_{300} \mathrm{~g}$ & 1.59 & 0.41 & 0.78 & 186.1 & 23.54 & 348.91 & 6.80 \\
\hline S.Em \pm & 0.01 & 0.01 & 0.01 & 0.42 & 0.15 & 1.77 & 0.03 \\
\hline C.D. at $5 \%$ & 0.03 & 0.02 & 0.02 & 0.90 & 0.32 & 3.75 & 0.07 \\
\hline
\end{tabular}

content of nitrogen $(1.59 \%)$ phosphorus $(0.41 \%)$ and potassium $(0.78 \%)$ was recorded from the tree which, received highest dose of NPK $\left(\mathrm{N}_{500} \mathrm{P}_{300} \mathrm{~K}_{300} \mathrm{~g} /\right.$ tree/ year). Among the organic manures, maximum foliar nitrogen $(1.57 \%)$ and phosphorus $(0.39 \%)$ were estimated from the trees with vermicompost at $4.0 \mathrm{~kg}$ tree while foliar potassium content $(0.76 \%)$ was recorded from the treatment with cowdung at $20 \mathrm{~kg} /$ tree.

\section{Soil NPK and pH status}

To know the effect of different manurial treatments on soil NPK status, soil samples were collected every year after harvest of the crop and average of three years has been presented in Table 3. It is clear from the data that the soil NPK status was improved irrespective of the treatments as compared to its initial values (before starting of 
experiment). Highest $\mathrm{N}, \mathrm{P}$ and $\mathrm{K}$ content in the soil $(0-30 \mathrm{~cm}$ depth) was estimated from the soil of the tree where highest NPK dose was applied $\left(\mathrm{N}_{500} \mathrm{P}_{300} \mathrm{~K}_{300} \mathrm{~g} /\right.$ tree $)$ and this treatment also resulted in highest fruit yield. Next higher soil NPK values were estimated from the treatment $\mathrm{N}_{400} \mathrm{P}_{200} \mathrm{~K}_{200} \mathrm{~g} /$ tree followed by mustard cake at $4.0 \mathrm{~kg} /$ tree. Another interesting observation noted was that soil NPK values were lower with vermicompost at $4.0 \mathrm{~kg} /$ tree as compared to 8.0 $\mathrm{kg} /$ tree which indicated that vermicompost at 4.0 $\mathrm{kg} /$ tree is sufficient to meet the 'sink' demand as because vermicompost at $4.00 \mathrm{~kg}$ resulted in higher yield and gave best quality fruit when vermicompost alone is considered.

Soil $\mathrm{pH}$ 'change' as noted due to application of manures and inorganic nutrients (i.e., fertilizers) may not be considered as 'affected' (Table 3 ). If we compare with the initial value (6.60), then we could say that $\mathrm{pH}$ was slightly increased towards 'neutral' irrespective of the treatments which may be due to inherent nature of the soil (New alluvial gangetic soil).

\section{Economic of the treatments}

Calculation of economic viability of the treatments is considered to be the last step for final recommendation of any package and practices related to agricultural/horticultural production. In the present investigation saleable product was ripe jackfruit. Production capacity of tree varied due to application of different manorial treatments. The fruit yield per tree has been converted to a hectare considering 100 trees at $10 \times 10 \mathrm{~m}$ spacing (Table 4). Cost of each treatment application, gross return and net return per

Table 4. Economic analysis of different nutrient management practices in jackfruit

\begin{tabular}{|c|c|c|c|c|c|c|}
\hline \multirow{2}{*}{$\begin{array}{l}\text { Treatment } \\
\text { per } \\
\text { tree / year }\end{array}$} & \multicolumn{2}{|c|}{ *Yield of jackfruit ${ }^{G r o s s}$} & \multirow{2}{*}{$\begin{array}{l}\text { Cost of } \\
\text { Income/ha } \\
\text { (Rs.) }\end{array}$} & \multirow{2}{*}{$\begin{array}{c}\text { Net } \\
\text { treatments/ ha } \\
\text { (Rs.) }\end{array}$} & \multirow{2}{*}{$\begin{array}{c}\text { Benefit } \\
\text { profit/ha } \\
\text { (Rs.) }\end{array}$} & \multirow{2}{*}{$\begin{array}{c}\text { cost ratio } \\
\text { (BCR) }\end{array}$} \\
\hline & Per tree $(\mathrm{kg})$ & Per ha (kg) & & & & \\
\hline Cowdung-20 kg & 53.1 & 5310.00 & $79,650.00$ & $44,947.00$ & $34,703.00$ & 1.77 \\
\hline Cowdung $-40 \mathrm{~kg}$ & 38.7 & 3870.00 & $58,050.00$ & $52,947.00$ & $5,103.00$ & 1.10 \\
\hline Mustard Cake $-2 \mathrm{~kg}$ & 41.7 & 4170.00 & $62,550.00$ & $40,347.00$ & $22,203.00$ & 1.55 \\
\hline Mustard Cake $-4 \mathrm{~kg}$ & 52.9 & 5290.00 & $79,350.00$ & $43,747.00$ & $35,603.00$ & 1.81 \\
\hline Vermicompost $-4 \mathrm{~kg}$ & 56.3 & 5630.00 & $84,450.00$ & $38,947.00$ & $45,503.00$ & 2.17 \\
\hline Vermicompost $-8 \mathrm{~kg}$ & 44.8 & 4480.00 & $67,200.00$ & $40,947.00$ & $26,253.00$ & 1.64 \\
\hline $\mathrm{N}_{200} \mathrm{P}_{100} \mathrm{~K}_{100} \mathrm{~g}$ & 51.9 & 5190.00 & $77,850.00$ & $59,900.00$ & $17,950.00$ & 2.00 \\
\hline $\mathrm{N}_{400} \mathrm{P}_{200} \mathrm{~K}_{200} \mathrm{~g}$ & 59.4 & 5940.00 & $89,100.00$ & $82,100.00$ & $7,000.00$ & 1.09 \\
\hline $\mathrm{N}_{500} \mathrm{P}_{300} \mathrm{~K}_{300} \mathrm{~g}$ & 76.3 & 7630.00 & $1,14,450.00$ & $1,01,102.00$ & $13,348.00$ & 1.13 \\
\hline
\end{tabular}

* Average of 3 years

hectare have also been presented in Table 4. It was observed that highest expenditure (Rs.1,01,102 /-) was incurred in the treatment of highest dose of NPK $\left(\mathrm{N}_{500} \mathrm{P}_{300} \mathrm{~K}_{300} \mathrm{~g} /\right.$ tree/year) which gave highest yield and thus resulting lower BCR (1.13) as compared to its lowest dose $\left(\mathrm{N}_{200} \mathrm{P}_{100} \mathrm{~K}_{100} \mathrm{~g} /\right.$ tree/year). Although, the lowest dose of inorganic fertilizers gave lowest yield as compared to other higher doses but BCR was highest (2.00). However, highest BCR of 2.17 was calculated from the treatment of vermicompost at 4.0 $\mathrm{kg} /$ tree/year.

\section{CONCLUSIONS}

From the economic calculation and comparison among the different treatments, it can be concluded that vermicompost at $4.00 \mathrm{~kg} /$ tree/year should be adopted under organic jack culture. Combined application of organic manures and inorganic fertilizers in fruit trees is now emerging as integrated nutrient supply (INS) approach for sustainable higher production of quality fruits. In this angle, application of vermicompost at $4.00 \mathrm{~kg}$ and $\mathrm{N}_{200} \mathrm{P}_{100} \mathrm{~K}_{100} \mathrm{~g} /$ tree/year together may be considered. 


\section{REFERENCES}

A.O.A.C. 1990. Official Methods of Analysis. Association of Official Agriculture Chemists (15 ${ }^{\text {th }}$ Edn.), Washington, D. C.

Anwar, R., Ahmad, S., Yaseen, M., Ahmad, W. and Nafees, M. 2011. Bimonthly nutrient application programme on calcareous soil improves flowering and fruit set in mango (Mangifera indica L.). Pak. J. Bot., 43(2): 983-990.

Bhargava, B. S. and Chadha, K. L. 1993. Leaf nutrient guide for fruit crops, In: Advances in Horticultural Fruit Crops 2 Eds. Chadha K.L. and Pareek O.P. Malhotra Publishing House, New Delhi. pp.973-1030.

Black, C.A .1965. Methods of Soil Analysis Part-II, Agronomy monograph, No. 9. American Society of Agronomy, Madison, Wicconsin, pp. 148.

Bray, R. H. and Kurtz, L.T. 1945. Determination of total organic and available forms of phosphorus on soils. Soil Sci. 50: 39-45.

Hossain, A.K.M.A. and Haq, N. 2006. Jackfruit, Artocarpus heterophyllus, Field Manual for Extension Workers and Farmers, SCUC, Southampton University, UK.
Jackson, M. L. 1973. Soil Chemical Analysis, Prentice Hall of India Pvt. Ltd., New Delhi, Ed.2, pp. 82-111.

Jackson, W.L. 1967. Soil Chemical Analysis, Prentice Hall of India Pvt. Ltd., New Delhi, pp. 183-192.

Klein, I. and S .A. Weinbaum. 1984. Foliar application of urea to olive: Translocation of urea nitrogen as influenced by sink demand and nitrogen deficiency. J. Amer. Soc. Hort. Sci., 109: 356360.

Piper, C.S. 1956. Soil and Plant Analysis. Waite Agric. Res.Ins. South Australia.

Tandon, H.L.S. 1987. Fertilizer Recommendations for Horticultural Crops in India - A Guidebook. Fertilizer Development and Consultation Organisation, New Delhi, India. pp. 112.

Usherwood, N. R. 1985. The role of potassium in crop quality. In: Potassium in Agriculture. Ed. Munson, R.S., ASA-CSSA-SSSA, Madison, WI, pp. 489-513.

(MS Received 20 June 2017, Revised 13 January 2018, Accepted 17 April 2018) 